\title{
CHEMICAL COMPOSITION, ANTIOXIDANT AND CYTOTOXIC ACTIVITIES OF ONOPORDUM ACANTHIUM L. CRUDE OIL AND DEFATTED MEAL
}

\author{
Moufida A. OUESLATI, ${ }^{\mathrm{a}}$ * Aynur GUNENC, ${ }^{\mathrm{b}}$ Ghayth RIGANE, ${ }^{\mathrm{c}, \mathrm{d}}$ Hanen GHAZGHAZI, \\ Caroline VALENCIA, ${ }^{\mathrm{f}}$ Ridha BEN SALEM, ${ }^{\mathrm{c}}$ Sadok BOUKHCHINA, ${ }^{\mathrm{g}}$ Williamn G. WILLMORE ${ }^{\mathrm{b}}$ \\ and Farah HOSSEINIAN ${ }^{\mathrm{b}}$ \\ $\mathrm{a}^{*}$ College of Applied Medical Sciences of al Jubail, Deanship of preparatory year and supporting studies and the department \\ of Respiratory Care, Imam Abdulrahman Bin Faisal University, PO. Box 1982, Dammam 31441, Saudi Arabia \\ ${ }^{\mathrm{b}}$ Institute of Biochemistry, Food Science and Nutrition Division, Department of Chemistry and Department of Biology, \\ Carleton University, Ottawa, Ontario, Canada K1S 5B6 \\ ${ }^{c}$ Organic Chemistry Laboratory LR17ES08, Department of Chemistry, Faculty of Sciences of Sfax, \\ B.P « $1171 » 3038$ Sfax, University of Sfax, Tunisia \\ ${ }^{\mathrm{d} C h e m i s t r y-P h y s i c s ~ D e p a r t m e n t, ~ S c i e n c e s ~ a n d ~ T e c h n o l o g y, ~ F a c u l t y ~ o f ~ S i d i ~ B o u z i d, ~ B . ~ P . ~ 380, ~ 9100, ~}$ \\ Sidi Bouzid, University of Kairouan, Tunisia \\ ${ }^{\mathrm{e}}$ Laboratory of Management and valorization of Forest Resources National institute of research in Rural Engeneering, \\ water and forests (INRGREF) of Tunis, Tunisia \\ ${ }^{\mathrm{f}}$ National Institute of Agronomic Sciences, Nutrition and Environment. 21079 Dijon Cedex, France \\ ${ }^{g}$ Laboratory of lipids biochemistry, Department of Biology, University of Sciences of Tunis, 2092 El Manar II Tunisia
}

In the present study, the seed oil from Onopordum acanthium. L and methanolic extract of the defatted meal were evaluated for their cytotoxic effect and antioxidant potential. The phenolic composition of the defatted meal was determined with RP-HPLC-UV and tocopherols levels in the crude oil were also assessed. Overall, the methanolic extract exhibited the best amount of total phenolics and flavonoids content $(78.06 \pm 0.55$ $\mathrm{mg} \mathrm{GAE} / \mathrm{g}$ on DW basis and $20.38 \pm 0.21 \mathrm{mg} \mathrm{RE} / \mathrm{g}$ on DW basis, respectively).Seven phenolic compounds were identified with cinnamic acids as the major components (67.2\%) and epicatechin

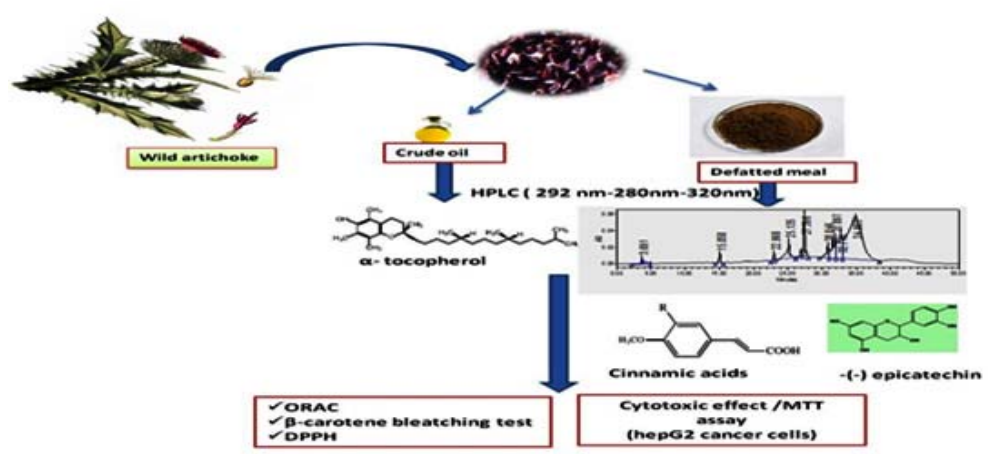
was the dominant flavan-3-ol. Additionally, three individual tocopherols were determined and $\alpha$-tocopherol was the main isomer $(914.8 \pm 0.02 \mathrm{mg} / \mathrm{kg})$. Data of antioxidant performance showed superior antioxidant capacity in methanol extract. Moreover methanolic extract from defatted seeds was more active towards HepG2 cancer cells than the crude oil $\left(\mathrm{IC}_{50}\right.$ of $\left.44.05 \pm 3.54 \mu \mathrm{g} / \mathrm{ml}\right)$ and showed less cytotoxicity towards AML12 normal hepatocytes in comparison to doxorubicin indicating at least some tumor-specific action.

\section{INTRODUCTION}

In the present study, the attention was focused on Onopordum acanthium L. (O. acanthium) known as wild artichoke ${ }^{1}$ which is one of the important genera within the asteraceae family. It is a highly reputable plant as a source of constituents with promising bioactivity to be exploited at many domains. $O$. acanthium is widely distributed over the world. The plant is characterized by significant

* Corresponding authors: maalweslati@iau.edu.sa 
fruit and biomass productivity. Consequently, the species is gaining interest as a potential novel commercial crop for multiple uses. In Tunisia, $O$. acanthium is widely distributed in open areas, roads, path margins, fallow land and meadows. ${ }^{2}$ Previous works ${ }^{3,4}$ have studied the chemical composition of Onopordum species and a number of secondary metabolites were identified. ${ }^{5}$ Nevertheless, to the best of our knowledge, no study has investigated the biochemical composition and the therapeutic value of $O$. acanthium seed fractions. Indeed, residues of defatted seeds are usually treated as a detergent or organic fertilizer, which renders them with very low economic value. Moreover, the wild artichoke, as many asteraceae species exhibits very interesting traits and their byproducts are finding various applications. Therefore, it is important to acquire a better knowledge of their properties in order to optimize the use of these materials. In the current study content of tocopherols in the crude oil and phenolics in Methanol defatted meal extract were determined. In addition, their antioxidant profile and antiproliferative potential towards HepG2 carcinoma cell line were evaluated. These data will offer a strong frame work for new discoveries, particularly in the pharmaceutical, cosmetic and agri-food processing industries.

\section{RESULTS AND DISCUSSION}

\section{Total phenolics, flavonoids and condensed tannin content}

Quantitative determination of the flavonoids and condensed tannin of the aforementioned grain fractions and their respective total phenol contents are presented in Table 1. Our results demonstrate defatted seeds are a rich source of phenolic compounds with $78.06 \pm 5.5 \mathrm{mg} \mathrm{GAE} / \mathrm{g}$ on DW basis which is 18.49 fold higher than that of the crude oil. The same result was observed for total flavonoids and condensed tannin for which only minor amounts (1.11 mg CE/g on DW basis) were detected in the crude oil. Even though the solubility of phenolic molecules in the oil is poor, small amounts were carried over into the oil through the extraction procedure. These findings are in agreement with literature data showing that procyanidins determined by the vanillin assay were detectable in small amounts in many crude oils. ${ }^{6}$ Furthermore, in comparison to other asteraceae species, phenolic content of deffated seeds is significantly higher than that found in many asteraceae species and other herbaceous species like Cosmos caudatus, polygonum minus and Centella asiatica. ${ }^{7}$ Our findings showed the richness of $O$. acanthium defatted seeds, normally used as organic fertilizers, on phenolic compounds which are known to possess important healthprotecting effects.

\section{Analysis of individual phenolic compounds by analytical RP-HPLC}

A total of seven phenolic compounds ( $\mathrm{mg} / 100 \mathrm{~g}$ of on DW basis) were identified in the methanolic extract of defatted meal (Table 2), where five as phenolic acids: syringic, $p$-coumaric, $m$-coumaric, $o$ - coumaric and trans-cinnamic acid. Moreover, two flavan-3-ols: (-)-epicatechin and (+)- catechin were detected at $320 \mathrm{~nm}$ and $280 \mathrm{~nm}$, respectively. Interestingly, cinnamic acids were the major phenolic components $(67.2 \%)$ and trans-cinnamic acid was identified for the first time in $O$. acanthium seeds $(132.9 \pm 3.28 \mathrm{mg} / 100 \mathrm{~g}$ on DW basis). (+)-catechin and (-)-epicatechin was detected in methanolic extract with $3.53 \pm 0.28$ and $48.2 \pm$ $2.4 \mathrm{mg} / 100 \mathrm{~g}$ on DW basis respectively showing that the procyanidin fraction is dominated by (-)epicatechin which could be referred to the conversion of $(+)$-catechin to its isomer (-)-epicathechin under the extraction conditions.

\section{Table 1}

Phenolic content (Total phenolic, condensed tanin and flavonoid content) of O.acanthium seed oil and methanol extract of defatted seeds

\begin{tabular}{lcccc}
\cline { 2 - 5 } & $\begin{array}{c}\text { Phenolic } \\
\text { content }(\mathrm{mg} \\
\left.\mathrm{GAE}^{\mathrm{a}} / \mathrm{g}\right)\end{array}$ & $\begin{array}{c}\text { Flavonoid } \\
\text { content }(\mathrm{mg} \\
\left.\mathrm{RE}^{\mathrm{c}} / \mathrm{g}\right)\end{array}$ & $\begin{array}{c}\text { Tanin content } \\
\left(\mathrm{mg} \mathrm{CE}^{\mathrm{b}} / \mathrm{g}\right)\end{array}$ & $\begin{array}{c}\text { Extraction } \\
\text { yield (\%) }\end{array}$ \\
\hline Deffated seeds $^{\mathrm{d}}$ & $78.06 \pm 5.5^{\mathrm{g}}$ & $20.38 . \pm 2.1^{\mathrm{k}}$ & $9.37 \pm 0.18^{\mathrm{i}}$ & $23.1 \pm 1.3$ \\
\hline Seed oil $^{\mathrm{e}}$ & $4.22 \pm 0.82^{\mathrm{h}}$ & $2.46 \pm 0.54^{1}$ & $1.11 \pm 0.1^{\mathrm{j}}$ & $\mathrm{nde}^{\mathrm{f}}$ \\
\hline
\end{tabular}

Concentration of phenolic content is expressed as mg gallic acid equivalent $\left({ }^{\mathrm{a}}\right)$, catechin equivalent $\left({ }^{\mathrm{b}}\right)$ and rutin equivalent $\left({ }^{c}\right)$ per gramme of dry weight $\left({ }^{d}\right)$ and per $g$ of oil $\left({ }^{e}\right)$ for total phenolics, tannins and flavonoids respectively. ${ }^{\mathrm{f}}$ nde, not determined. 
Table 2

HPLC data of phenolic compounds in O. acanthium defatted meal extract

\begin{tabular}{lll}
\hline $\begin{array}{l}\text { Phenolic compounds } \\
\left(\mathbf{m g} / \mathbf{1 0 0 g} \text { on DW } \text { basis }^{\mathbf{a}}\right)\end{array}$ & ${\text { RRT }(\mathbf{m i n})^{\mathbf{b}}}^{\mathbf{b}}$ & $\mathbf{M e O H}^{\mathrm{c}}$ extract \\
\hline Catechin & 15.63 & $3.53 \pm 0.28^{\mathrm{f}}$ \\
Syringic acid & 23.03 & $1.66 \pm 0.64^{\mathrm{g}}$ \\
$p$-coumaric acid & 25.2 & $21.03 \pm 1.94^{\mathrm{h}}$ \\
$m$-coumaric acid & 27.51 & $65.4 \pm 2.84^{\mathrm{i}}$ \\
$o$ - coumaric acid & 30.7 & $2.56 \pm 0.75^{\mathrm{g}}$ \\
Trans-cinnamic acid & 35.54 & $132.9 \pm 3.8^{\mathrm{k}}$ \\
Epicatechin $(320 \mathrm{~nm})$ & 27.11 & $48.2 \pm 2.4^{1}$ \\
UP $^{\mathrm{d}}$ & & $54.83 \pm 1.56^{\mathrm{m}}$ \\
\hline
\end{tabular}

${ }^{b} \mathrm{RRT}$, Relative retention time; ${ }^{\mathrm{c}} \mathrm{MeOH}$, Methanol extract: ${ }^{\mathrm{a}}$ on DW basis, dry weight ${ }^{\mathrm{d}} \mathrm{UP}$, Unknown peaks; Means values with different letters ( $\mathrm{f}-\mathrm{m}$ ) within a same line are significantly different at $p \leq 0.05$. Each value is a mean \pm standard deviation of at least triplicate analyses.

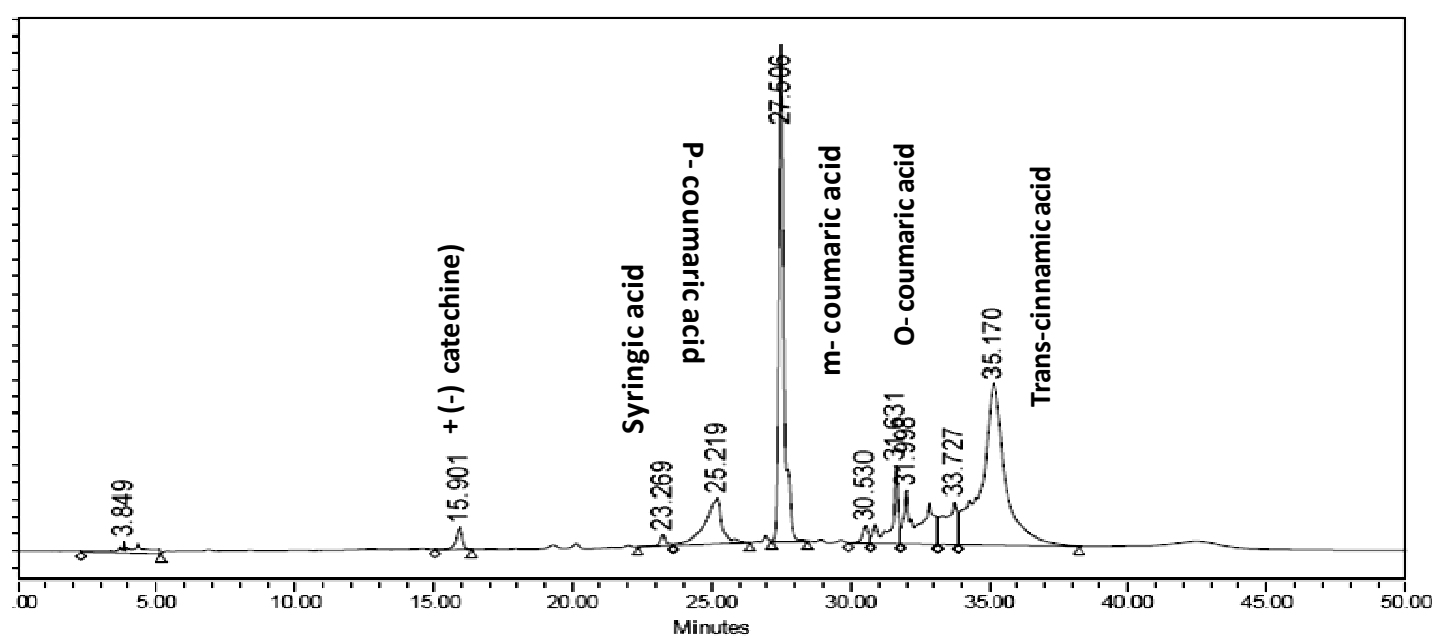

Fig. 1 - HPLC chromatogram profile of phenolic compounds in the methanol extract of $O$. acanthium seeds defatted meal (UV detection at $280 \mathrm{~nm}$ ).

Chon et al. ${ }^{8}$ and Nalewajko-Sieliwoniuk et al. ${ }^{9}$ have studied the phenolic composition of leaves and flowers of different asteraceae species and their result showed that only syringic, $p$-coumaric and trans-cinnamic acids are the common phenolic acids. Nevertheless, among all phenolic acids, special interest has been assigned to trans-cinnamic acid. According to previous publications ${ }^{10}$, transcinnamic acid is known to display different biological characteristics and have a pharmacokinetic profile that is notably anti-cancer agent and could therefore, constitute an added value in term of antioxidant potential of O.acanthium seeds.

\section{Tocopherols content}

In the present work, and as continuity with our previous work ${ }^{2}$ the seed oil was characterized in term of tocopherols content since this class of molecules is endowed with high antioxidant potential. Their content expressed as $\mathrm{mg} / \mathrm{kg}$ of oil was presented in
Table 3. Seeds are rich in tocopherols $(1809.22 \pm 2.4$ $\mathrm{mg} / \mathrm{kg}$ of oil) with $\alpha$-tocopherol as the major component

(914.8

$0.02 \mathrm{mg} / \mathrm{kg}$ ) followed by beta and gamma tocopherols that exhibited nearly the same amount (Fig. 2). Indeed, the obtained concentration of $\alpha$ tocopherol was significantly higher than that of many edible oils ${ }^{11}$ including, cold extra virgin oil (163.3 $\mathrm{mg} / \mathrm{kg}$ ), sunflower $(432 \mathrm{mg} / \mathrm{kg})$ and corn oil (173 $\mathrm{mg} / \mathrm{kg}$ ) but is in accordance to that found by Zhelev et al. ${ }^{12}$ who studied the same species. On the other hand, the concentration of $\beta$ and $\gamma$-tocopherol obtained in this study was higher than the values found in sunflower oil. ${ }^{11}$ It is therefore clear that $O$. acanthium crude oil is an important source of tocopherols and could be used in food and pharmaceutical industries since the three isomers are regarded as the most potent free-radical removers. Furthermore, several studies have shown that the former isomers have strong anti-inflammatory and anti-carcinogenic activities. ${ }^{13}$ 
Table 3

Tocopherols composition and content of O.acanthium seed oil

\begin{tabular}{lcl}
\hline Tocopherols & RTT $(\mathbf{m i n})^{\mathbf{a}}$ & $\mathbf{~ m g} / \mathbf{k g}$ of oil \\
\hline$\alpha$-Tocopherol & 14.59 & $914.80 \pm 0.02^{1}$ \\
$\beta$-tocopherol & 15.79 & $457.80 \pm 0.04^{\mathrm{m}}$ \\
$\gamma$-tocopherol & 16.25 & $437.40 \pm 0.03^{\mathrm{m}}$ \\
Total tocopherols & & $1809.22 \pm 2.4$ \\
oil content (g/kg on DW basis) & & $152.66 \pm 3.55$ \\
\hline
\end{tabular}

${ }^{a}$ RRT: Relative retention time; Means followed by the same letter do not differ significantly at $P<0.05$ level.

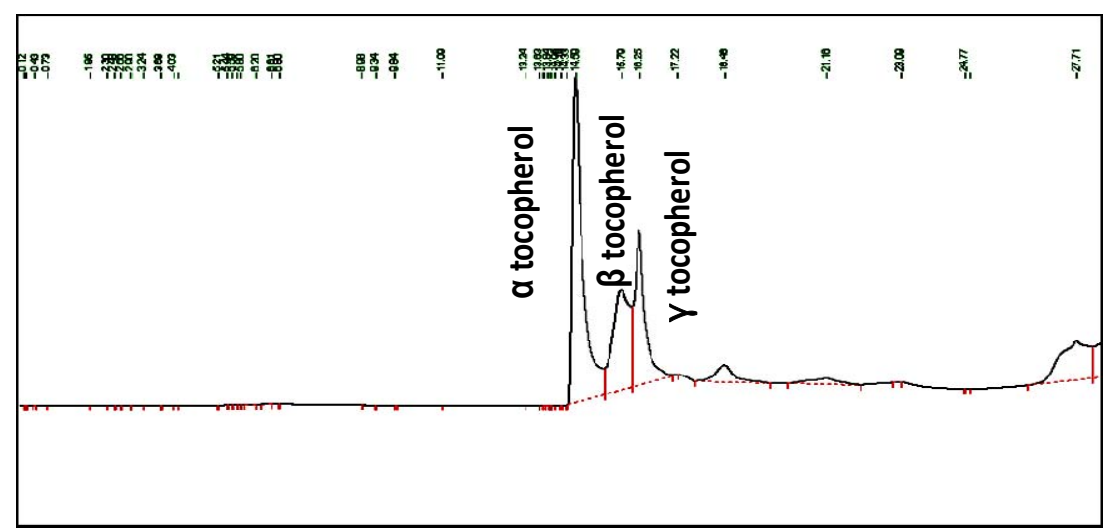

Fig. 2 - HPLC profile of Alpha, Beta and gamma Tocopherols detected in the seed oil of Onopordum acanthium.

Table 4

Antioxidant activity values of O.acanthium defatted meal and crude oil assessed using ORAC assay, $\beta$-carotene bleaching, and DPPH tests

\begin{tabular}{l|c|c|c}
\hline \multicolumn{2}{c}{ ORAC assay } & B-carotene bleaching test & DPPH assay \\
& $\mu \mathrm{mol} \mathrm{TE} / \mathbf{m g}$ on DW basis & IC50 $^{\mathrm{b}}$ (\% of extract) & IC50 (\% of extract) \\
\hline Seed oil & $0.117 \pm 0.01^{\mathrm{d}}$ & $22.04 \pm 2.3^{\mathrm{i}}$ & $8.75 \pm 2.24^{\mathrm{q}}$ \\
MeOH $^{* *}$ & $5.64 \pm 1.85^{\mathrm{l}}$ & $3.72 \pm 0.81^{\mathrm{h}}$ & $4.35 \pm 0.14^{\mathrm{s}}$ \\
BHT $^{\mathbf{v}}$ & & $17.4 \pm 0.02^{\mathrm{n}}$ &
\end{tabular}

${ }^{a}$ Oxygene radical absobance capacity (ORAC) values are expressed as Trolox equivalent per mg of dry weight, Methanolic extract at a concentration of $1 \mathrm{mg} / \mathrm{ml}$, BHT at $4 \mathrm{mg} / \mathrm{ml}$ and quercetin at $0.1 \mathrm{mg} / \mathrm{ml}$, was regarded as a concentration of $100 \%$. MeOH, Methanol extract. Means with different letters are significantly different $(\mathrm{P} \leq 0.05)$.

\section{Antioxidant properties}

According to previous publications, the estimation of antioxidant capacities of many crops using more than one test is strongly encouraged. Therefore, the investigation of antiradical activity was assessed by using three complementary assays: DPPH test, linoleic acid emulsion model systems and ORAC assay. Results show that the common point between the three tests is the high antioxidant activity of the methanol extract of the defatted meal in comparison to the hydrophobic fraction as shown in Table 4. In ORAC assay, the antioxidant activity was calculated by using a Trolox standard curve $\left(\mathrm{y}=0.120 x-0.134, \mathrm{r}^{2}=0.99\right)$. The methanol fraction showed the highest ORAC values $(5.64 \pm$ 
$1.85 \mu \mathrm{MTE} / \mathrm{mg}$ of on DW basis), followed by the cypsela oil which was 48.2 -fold less. On the other hand, according to the RSA results and compared to the standard control (quercetin), both seed fractions were able to quench the DPPH free radical during $30 \mathrm{~min}$ of incubation with $\mathrm{IC}_{50}$ values of $4.35 \%(43.5 \pm 1.44 \mu \mathrm{g} / \mathrm{ml})$ and $8.75 \pm$ $2.24 \%$ respectively. Furthermore, the result of the antioxidant power of the former achenes fractions assessed with the $\beta$-carotene bleaching test, showed that the methanolic extract which significantly $(p<0.01)$ exceed the synthetic antioxidant BHT used as a positive control $\left(\mathrm{IC}_{50}=\right.$ $3.72 \%$ vs. $17.4 \%$ ) possesses an inhibition ratio that ranges from $97.56 \pm 0.48$ to $26.08 \pm 0.54$ (result not shown) when the concentration varied from 1000 to $5 \mu \mathrm{g} / \mathrm{ml}$. Additionally seed oil performed good activity when compared to BHT $(94.87 \pm 2.7 \%$ at $4 \mathrm{mg} / \mathrm{ml}$ ). The antioxidant activity of the crude oil varied from $95.7 \pm 0.48 \%$, when concentrated $(100 \%)$ to $13.2 \pm 0.3 \%$ at a concentration of $6.25 \%$. However when compared to the organic extract, the vegetable oil seems to be less active toward the linoleate free radicals and other radicals formed within the emulsion system.

The regression analysis between the above three tests show, a high correlation between ORAC and $\beta$-carotene bleaching assays $\left(\mathrm{r}^{2}=0.981\right)$ where as low correlation where observed between the above assays and DPPH test $\left(r^{2}=0.73\right.$ and 0.6 respectively). The observed discrepancy may reflect a relative difference in the ability of antioxidant compounds in methanol extract (phenolics, saponosides, sesquiterpenes, etc,...) and the oil (tocopherols, fatty acids, phytosterols) to quench peroxyl radicals (ROO) and to reduce $\mathrm{DPPH}$ free radical in in vitro systems. Definitely, Fotti et al. (2004) ${ }^{14}$ have shown that the extraction solvent could modulate the capacity of phenolic compounds to transfer an electron or a proton to the free radical. Hence, the high antioxidant activity of methanol extract could be due to its strong hydrogen-bond-accepting capacity (hydroxylic solvent) and its relatively high dielectric constant that supports well the ionization of acids and the electron transfer process. Data of antioxidant performance of seed fractions suggest methanol extract from seed residue and less the crude oil possess an important in vitro antioxidant capacity that could support the ethno phar- macological use of $O$. acanthium seeds in pathologies implicating ROS. These findings motivated us to go further and study the cytotoxic effect of the achenes.

\section{Anti-proliferative effect}

The dose-dependent effect of the crude extract and oil on proliferation of hepatocarcinoma cell line is shown in Figure 3. Treated cells exhibited a dose dependent decline in viability. Methanol extract was able to inhibit cell proliferation with a $\mathrm{IC}_{50}$ value of $44.05 \pm 3.54 \mu \mathrm{g} / \mathrm{ml}$ versus $0.7 \pm 0.024 \mu \mathrm{g} / \mathrm{ml}$ for doxorubicin (Table 5), whereas the crude oil has recorded less cytotoxic effect on HepG2 cell line with an $\mathrm{IC}_{50}$ of $38.1 \pm 0.6 \%$ of oil. Compared to active seed fractions, doxorubicin evoked greater toxicity in both cells whereas the methanol extract showed less cytotoxicity towards AML12 normal hepatocytes with $\mathrm{IC}_{50}$ of $117.31 \pm 2.66 \mu \mathrm{g} / \mathrm{ml}$ (Table 5 ), indicating at least some tumor-specific action of this fraction. Nevertheless, despite the richness of the vegetable oil in tocopherols notably alpha tocopherol and other bioactive molecules ${ }^{7}$, HepG2 cells were more sensitive to the organic extract from defatted seeds, than the hydrophobic fraction. This could be explained by the lack of incorporation of the oil into tumor cells. These data provided evidence that active defatted seed fractions fulfill 2 basic criteria for an effective therapeutic substances i.e; tumor specificity and minimal toxicity towards the normal cells. Moreover, the observed effect was dose dependent, which may result from the synergistic effect of phenolic compounds and their functional groups. Previous studies have reported that the use of whole extract is more effective than using any single constituent. ${ }^{15}$ Although, this cannot neglect the role of trans-cinnamic acid as the major phenolic acid identified in seeds. Indeed, the chemo preventive role of trans-cinnamic acid via the activation of the antioxidant enzymes is well documented. Patra et al. ${ }^{16}$ have demonstrated that pretreatment of cells by cinnamic acid significantly elevated the three antioxidant enzyme levels (superoxide dismutase, glutathione S-transferase and catalase). It is therefore clear that methanol extract of $O$. acanthium seed residue have chemo preventive activity and seeds could be considered as potential source of anticancer compounds. 


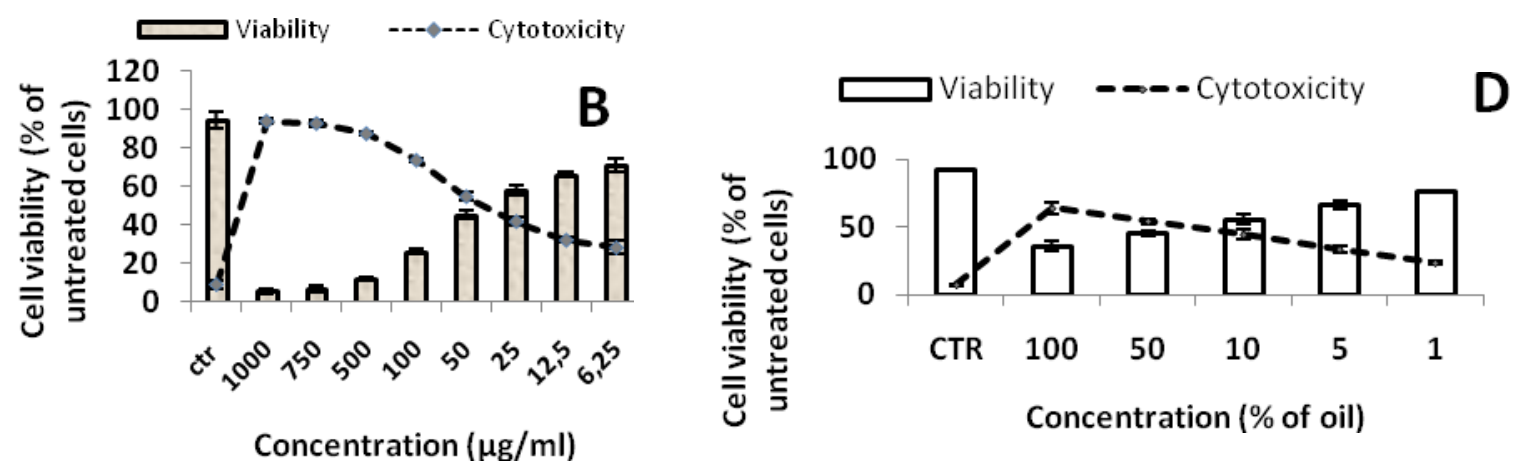

Fig. 3 - Viability of HepG2 cells cultured with different concentrations of $O$. acanthium seed extracts, B: Methanol extract and D: seed oil, analysed by MTT assay. Results are shown as means $\pm \mathrm{SD}(\mathrm{n}=3)$. Ctr, control.

Table 5

Cytotoxic activity of the crude oil and methanol extract from $\mathrm{O}$. acanthium seeds and doxorubicin after 24h treatment in HepG2 cancer cells and AML12 normal cells

\begin{tabular}{lll}
\hline & & IC50 $^{\mathbf{a}}$ \\
\hline extracts & HepG2 & AML12 \\
\hline Methanolic & $44.05 \pm 3.54^{\mathrm{ce}}$ & $117.31 \pm 2.66^{1}$ \\
Seed oil (\%) & $38.1 \pm 0.6^{\mathrm{f}}$ & $71.55 \pm 1.14^{\mathrm{j}}$ \\
Doxorubicin $^{\mathrm{b}}$ & $0.7 \pm 0.024^{\mathrm{g}}$ & $18.67 \pm 0.3^{\mathrm{k}}$ \\
\hline
\end{tabular}

a, IC50 values are expressed in $\mu \mathrm{g} / \mathrm{ml}$ for extracts and in percent of total lipids for the vegetable oil; b, Standard anticancer drug and positive control; Values within the same column with different letters are significantly different at $\mathrm{p} \leq 0.05$.

\section{EXPERIMENTAL}

\section{Plant material and extracts preparation}

$O$. acanthium seeds were collected from plants growing wild in the El Kef area of north-western Tunisia. ${ }^{7}$ The voucher specimens (Onopordum acanthium L., voucher no. 1525) were deposited in the herbarium of the laboratory in the University of Sciences of Tunis. Following plant harvest, mature seeds were husked, cleaned and dried $\left(70^{\circ} \mathrm{C}\right)$. The oil was extracted using petroleum ether according to AOCS method. ${ }^{17}$ Subsequently, defatted seeds $(25 \mathrm{~g})$ have undergone the extraction of their phenolics using methanol. The extract was vacuum filtered through sintered glass, the residue re-suspended with the same volume of solvent and the extraction repeated twice. The supernatant obtained by vacuum filtration was concentrated and stored at $-20^{\circ} \mathrm{C}$ in the dark until further analysis.

\section{Phenolic content analysis}

Total phenolic, flavonoids and condensed tannin content of the seed residue and oil were determined by a spectrophotometric methods according to Gao et al., ${ }^{18}$ Malicanin et al., ${ }^{19}$ and Sun et al., ${ }^{20}$ respectively. The total phenol content was expressed as $\mathrm{mg}$ gallic acid equivalent ( $\mathrm{mg}$ GAE /g on DW basis), total flavonoids was expressed as mg rutin equivalent ( $\mathrm{mg} \mathrm{RE} / \mathrm{g}$ on DW basis) while, condensed tannin was expressed as $\mathrm{mg}$ catechin equivalent per gram of dry weight (mg CE/g on DW basis).

\section{Identification of individual phenolic compounds using RP-HPLC/UV}

Dried sample from $O$. acanthium defatted seeds was hydrolyzed according to the method of Proestos et al. ${ }^{21}$ with minor modifications. The acidic hydrolysis was monitored to release the aglycones in order to simplify the identification process. Therefore, $10 \mathrm{ml}$ methanol containing BHT (1g/l) were added to $0.25 \mathrm{~g}$ of a dried sample followed by $5 \mathrm{~mL}$ of $1 \mathrm{M} \mathrm{HCl}$. The mixture was stirred and sonicated for $15 \mathrm{~min}$ and refluxed in a water bath at $90^{\circ} \mathrm{C}$ for $2 \mathrm{~h}$. The obtained mixture was filtered through a $0.45 \mu \mathrm{m}$ membrane filter and then injected to HPLC. The phenolic compound analysis was carried out using an Alliance Waters Technologies e2695 series liquid chromatograph (RP-HPLC) equipped with a photodiode array detector (PDA, Waters 2998), Empower software, and auto sampler (Waters Corp., Milford, MA). The separation of phenolics was carried out on a $150 \mathrm{x} 4.6-\mathrm{mm}, 5 \mu \mathrm{M}$, an Atlantis RT3 column. The mobile phases consisted of $4 \%$ acetic acid (solvent A) and $99 \%$ methanol: acetic acid (solvent B) at $35^{\circ} \mathrm{C}$. The flow rate was kept at $0.5 \mathrm{ml} / \mathrm{min}$. The gradient program was as follows: solvent A: $0 \mathrm{~min}, 95 \%$; $15 \mathrm{~min}, 80 \% ; 20-25 \mathrm{~min}$, $60 \%$; 26-30 min, 20\%; 31-35 $\mathrm{min}, 80 \%$; and $36-50 \mathrm{~min} 95 \%$. The injection volume was $10 \mu \mathrm{l}$ for each sample, and peaks were monitored at 280 and $320 \mathrm{~nm}$ for phenolics and proanthocyanidins, respectively. Phenolic acids were identified according to their retention times and spectral characteristics of their peaks against those of standards (gallic acid, ferrulic acid, p-coumaric acid, OH-benzoic acid, chlorogenic acid, vanillic acid , syringic acid, $m$-coumaric acid, trans-cinamic acid, (+)catechin and (-)-epicatechin, vanillin and caffeine) and to the literature. $^{22}$ Peaks were quantified using a regression equation obtained from phenolic acids standard curve $(\mathrm{y}=$ $\left.7 \mathrm{E}+0.7 \mathrm{x}+7298.6, \mathrm{r}^{2}=0.9992\right)$. Phenolic acid content were expressed as $\mathrm{mg} / 100 \mathrm{~g}$ of dry weight.

\section{Quantification of tocopherols in seed oil}

Tocopherols were evaluated as described before by Deiana et $a l^{23} \alpha, \beta$, and $\gamma$-tocopherol standards were purified from 
extra virgin olive oil as it is described by Grigoriadou et al. ${ }^{24} \mathrm{An}$ accurate amount $(100 \mu \mathrm{L})$ of Onopordum acanthium oil seeds were dissolved in a $1 \mathrm{~mL}$ volume of Butanol/hexane $(50 / 50$, $\mathrm{v} / \mathrm{v}$ ) and homogenized. Sample preparation was conducted in dark until uses. Amounts of tocopherols were measured by Perkin Elmer apparatus, using a Series 200 pump (USA) equipped with a Series $200 \mathrm{UV} / \mathrm{Vis}$ detector (USA). The chromatographic separation was achieved with a C-18 Hewlett-Packard ODS Hypersil column $(5 \mu \mathrm{m}$ particle size, $100 \times 2.1 \mathrm{~mm}$ ) operating at $32{ }^{\circ} \mathrm{C}$. The mobile phase used was a mixture of methanol/ $\mathrm{CH}_{3} \mathrm{COONa} 0.05 \mathrm{M} \mathrm{pH} 5.5(95: 5, \mathrm{v} / \mathrm{v})$ at a flow rate of $0.3 \mathrm{~mL} / \mathrm{min}$, and the injection volume was $20 \mu \mathrm{L}$. The compounds were identified by chromatographic comparisons with authentic standards.

\section{Assessment of antioxidant activities}

ORAC assay: The ORAC of $O$. acanthium seed extract and diluted oil was applied according to the method described by Gunenc et al. ${ }^{25}$ Results were expressed as $\mu$ mol Trolox equivalent $/ \mathrm{mg}$ OF dry weight $(\mu \mathrm{M} \mathrm{TE} /$ on DW basis). All experiments were run in triplicate and averaged.

DPPH scavenging activity: The electron donating ability of the obtained oil and extract was measured by bleaching the purple-coloured solution of 1,1-diphenyl-2-picrylhydrazyl radical (DPPH) according to the method of $\mathrm{Li}$ et al. ${ }^{26}$ and Ramadan et $\mathrm{al}^{27}$ with some modifications. Quercetin $(0.1 \mathrm{mg} / \mathrm{mL})$ in $80 \%$ methanol was used as positive control. The Radical scavenging activity (RSA) was calculated as a percentage of DPPH discoloration using the equation; \%RSA= $\left(\left(\mathrm{A}_{\mathrm{DPPH}}-\mathrm{A}_{\mathrm{S}}\right) / \mathrm{A}_{\mathrm{DPPH}}\right)^{*} 100$, where $\mathrm{A}_{\mathrm{S}}$ is the absorbance of the solution containing the sample. The result was expressed as $\mathrm{IC}_{50}$ value (the extract concentrations providing $50 \%$ of antioxidant activity) calculated from the graph of DPPH scavenging activity against extract concentrations. Since the tested oil is expressed in $\%$ and in order to homogenize our result, methanol extract at a concentration of $1 \mathrm{mg} / \mathrm{ml}$ and quercetin at $0.1 \mathrm{mg} / \mathrm{ml}$ was regarded as a concentration of $100 \% . \mathrm{IC}_{50}$ values will be expressed in $\mu \mathrm{g} / \mathrm{ml}$ and in percent of extract.

$\beta$-carotene bleaching test: Antioxidant activity of methanolic extract of defatted seeds and oil was determined according to the version of the $\beta$-carotene bleaching method described by Koleva et al. ${ }^{28} \beta$-carotene bleaching inhibition was calculated using the following equation ( $\beta$-carotene content of assay/initial $\beta$-carotene content) $\times 100$. The result was expressed as $\mathrm{IC}_{50}$ value (the extract concentrations providing $50 \%$ of lipid peroxydation inhibition) calculated from the graph of $\beta$-carotene bleaching inhibition percentage against extract concentrations. BHT (from 4 to $0.125 \mathrm{mg} / \mathrm{ml}$, in $80 \%$ methanol) was used as positive control. $\mathrm{IC}_{50}$ values were expressed in $\mu \mathrm{g} / \mathrm{ml}$ and in percentage.

\section{Cell culture conditions}

Human liver carcinoma cell line (HepG2) (American Type Culture Collection (ATCC)) were generously provided by Dr. William Willmore (Institute of Biochemistry, Carleton University). Cells were cultured in Eagle's Minimal Essential Medium (EMEM) supplemented with 10\% fetal bovine serum (FBS) and $100 \mu \mathrm{g} / \mathrm{ml}$ gentamicine. HepG2 were grown in 75 square $\mathrm{mm}$ tissue culture flask and incubated in a humidified atmosphere containing $5 \% \mathrm{CO}_{2}$ at $37^{\circ} \mathrm{C}$ for $24 \mathrm{~h}$ to $70 \%$ confluency. The cell density was determined using trypan blue dye exclusion method and $5 \times 10^{4}$ cells $/ 100 \mu 1$ were used in the investigation of cytotoxic activity of $O$. acanthium seed fractions. Normal hepatocytes AML12 (ATCC) were used to test the cytotoxicity of seed products on normal cells. AML12 cells $(25000 /$ well) were maintained in DMEM -HamF12 complemented with $10 \% \mathrm{FBS}, 5 \mathrm{ml}$ ITS $100 \times$ (Insulin, Transferin, selenium) (GIBCO, life technology) and dexamethazone $(50 \mathrm{ng} / \mathrm{ml})$.

\section{Cytotoxicity assay}

Cytotoxic activity of the crude oil and methanol extract was determined according to Gliwa et al. ${ }^{29}$ with minor modifications. Cells were treated with various concentrations $(1000-6.25 \mu \mathrm{g} / \mathrm{mL})$ of $O$. acanthium defatted seeds extract and oil $(100-3.25 \%)$ with each concentration has been plated at least three times. The final concentration of solvent in the culture medium was maintained at $5 \%(\mathrm{v} / \mathrm{v})$. Untreated cells in which PBS was used instead of extract were considered as a negative control and doxorubicin $(0.3-20 \mu \mathrm{g} / \mathrm{mL})$ as a positive control. The result was expressed as $\mathrm{IC}_{50}$ values $(\mu \mathrm{g} / \mathrm{mL})$ that represent the sample's concentrations required to inhibit $50 \%$ of cell proliferation and was calculated from a calibration curve by linear regression using Microsoft Excel.

\section{Data analysis}

Statistical analysis of all data was performed using a Tukey's test followed by Dunn's post-hoc multiple comparison test (SPSS. v15). Pearson test was used to determine correlations between the different assays. All data was expressed as mean \pm standard deviation. A value of $\mathrm{p}<0.05$ was considered as statistically significant.

\section{CONCLUSION}

In the present investigation, we demonstrated the residue of $O$. acanthium seed oil production to be a polyphenol-rich by-product with high antioxidant activity. In addition, defatted seeds showed more selective cytotoxic activity against cancer cells than normal cells. This indicate that $O$. acanthium L. grain is a new botanical source that could provide useful therapeutic and preventive therapies for liver diseases and oxidative stress related diseases and suggest its use in the food industry as a potential and cheap source of antioxidant components notably $\alpha$-tocopherol and cinnamic acids. Furthermore, this study provides data that enhance the economic value of the defatted meal and procures veritable outlet for the technological channeling of this neglected bioresource limiting the problem of disposal.

Acknowledgements. The authors gratefully acknowledge Dr Justin Renaud for his reading and corrections. A large part of this work was carried out in the Institute of Biochemistry, the Division of Food Science and Nutrition, the Department of Chemistry, and the Department of Biology at Carleton University, Ottawa, Ontario, Canada. This study was funded by the Tunisian Ministry of Higher Education and Scientific Research. 


\section{REFERENCES}

1. P. B. Cavers, M. M. Qaderi, P. F. Threadgill and M. G. Steel, Can. J. Plant Sci., 2011,147,1.

2. O .A. Moufida, J. Renaud, H. Ghazghazi, S. Boukhchina and P. M. Mayer, Nat. Prod. Res., 2014, 28, 2293.

3. S. S. Azimova and A. I. Glushenkova, "Asteraceae", Chapter 3, London: Springer., 2011, p. 37-144.

4. S. U. Chon, Y. M. Kim and J. C. Lee, EWRS -Weed Research, 2003, 43, 444.

5. B. Csupor-Löffler, Z. Hajdù, B. Réthy, I. Zupko, I. Mthé, T. Rédei, G. Falkay and J. Hohmann, Phy. Res., 2009, 23, 1109.

6. M. S. Nikfardjam, Ph.D. Thesis, "Fachbereich Agrarwissenschaften, Ökotrophologie und Umweltmanagement”, Giessen, Germany, Justus von Liebig- Universität, 2001.

7. N. Huda-Faujan, A. Noriham, A. S. Norrakiah and A. S. Babji, Afr. J. Biotechnol., 2009, 8, 484-489.

8. S. U. Chon, Y. M. Kim and J. C. Lee, EWRS -Weed Research, 2003, 43, 444-450.

9. E. Nalewajko-Sieliwoniuk, J. Nazarukb, J. Kotowskaa and A. Kojłoa, Talanta, 2012, 96, 216.

10. K. Patra, S. Bose, S., Sarkar, J. Rakshit, S. Jana, A. Mukherjee, A. Roy, D. P. Mandal and S. Bhattacharjee, Chem. Biol. Interac., 2012, 195, 231.

11. E. C. Grilo, P. N. Costa, C. S. S. Gurgel, A. F. De Lima Beserra, F. N. De Souza Almeida and R. Dimenstein, Food Sci. Technol. Campinas, 2014, 34, 379.

12. I. Zhelev, P. Merdzhanov, M. Angelova-Romova, M. Zlatanova, G. Antova, I. Dimitrova-Dyulgerova and A. Stoyanova, Bulg. J. Agric. Sci., 2014, 20, 622.

13. J. Ju, S. C. Picinich, Z. Yang, Y. Zhao, N. Suh, A. N. Kong, C.S Yang, Carcinogenesis, 2010, 31, 533.

14. M. C. Fotti, C. Daquino and C. Geraci, J. Org. Chem., 2004, 69, 2309.
15. N. M. Yusri, K. W. Chan, S. Iqbal and M. Ismail, Molecules, 2012, 17,12612.

16. K. Patra, S. Bose, S. Sarkar, J. Rakshit, S. Jana, A. Mukherjee, A. Roy, D. P. Mandal and S. Bhattacharjee, Chem. Biol. Interac., 2012, 195, 231.

17. AOC (1989) Official Methods and recommended practices of the American oil Chemist's society. Champaign: American oil Chemist's society, Method Ce66.

18. L. Gao, S. Wang, B. D. Oomah , G. Mazza and G. St. Paul, MN: AACC International, 2002, 219-233.

19. M. Malicanim, V. Rac, V. Antié, M. Antié, L. M Palade, P. Kefelas and V. Rakié, J. Am. Oil Chem. Soc., 2014, DOI 10.1007/s11746-014-2441-2.

20. B. Sun, J. M. Richardo-da-Silvia and I. Spranger, J. Agric. Food Chem., 1998, 46, 4267.

21. C. Proestos, I. S. Boziaris, G. J. E. Nychas and M. Komaitis, Food Chem., 2006, 95, 664.

22. F. S Hosseinian and G. Mazza, J. Func. Foods, 2009, 1, 57.

23. M. Deiana, A. Rosa, C. Falqui, F. M Pirisi, G. Bandino and M. Assunta Dess, J. Agric. Food Chem., 2002, 50, 4342 .

24. D. Grigoriadou, A. Androulaki, E. Psomiadou and M. Z. Tsimidou, Food Chem., 2007, 105,675.

25. A. Gunenc and M. F. Hazinezhad, J. Func. Foods, 2015, DOI:10.1016/j.jff.2014.10.024.

26. W. Li, A. Hydamaka, L. Lowry and T. Beta, 2009, Versita. co-published with Springer-Verlag GmbH.

27. M. F. Ramadan, W. K. Lothar and J. T. Mörsel, J. Agric. Food Chem., 2003, 51, 6961.

28. I. L. Koleva, A. B. Teris, P. H. Jozef, A. G. Linssen and N. E. Lyuba, Phytochem. Anal., 2002, 13, 1.

29. J. Gliwa, A. Gunenc, N. Ames, W. G. Willmore and F. S. Hosseinian. J. Agric. Food Chem., 2011, 59, 11473. 